\title{
A RAINFOREST SURVEY OF AMPHIBIANS, REPTILES AND SMALL MAMMALS AT MONTAGNE D'AMBRE, MADAGASCAR
}

\author{
Christopher J. Raxworthy \& Ronald A. Nussbaum \\ Division of Herpetology, Museum of Zoology, University of Michigan, Ann Arbor, Michigan 48109, USA
}

(Received 3 November 1992; revised version received 17 June 1993; accepted 20 June 1993)

\begin{abstract}
The Montagne d'Ambre mountain range in northern Madagascar was surveyed for amphibians, reptiles, and small mammals. The rainforest of this region is geographically isolated from the continuous rainforest belt of northern and eastern Madagascar. A total of 24 amphibian, 46 reptile, and 12 mammal species was recorded over two months, by direct sampling and pitfall trapping. Despite previous collecting in this region for more than 100 years, $56 \%$ of the species found were new records for Montagne d'Ambre. Possibly seven (three amphibians, three reptiles, one small mammal) of the species recorded are undescribed, and nine are probably endemic to Montagne d'Ambre. The endemic species are Plethodontohyla sp. nov. 2 and 3, Brookesia sp. nov. I and 2, Paracontias brocchii, Zonosaurus haroldmeieri, Liopholidophis sp. nov., Pseudoxyrhopus ambreensis, and Microgale parvula. Published amphibian and reptile species lists for Montagne d'Ambre contained 26-40\% errors, which is probably typical for most sites in Madagascar, and cautions against using such sources of data indiscriminately.

The vast majority of species (83\%) were found only in primary forest, and the majority (70\%) had restricted altitudinal ranges, either occurring above or below $900 \mathrm{~m}$ elevation. The presence of low-altitude specialists at Montagne d'Ambre clearly demonstrates the need to conserve the lower altitude peripheral forests which are most vulnerable to encroachment and degradation.
\end{abstract}

Keywords: Madagascar, Amphibia, conservation, Mammalia, rainforest, Reptilia.

\section{INTRODUCTION}

Montagne d'Ambre, centered at $12^{\circ} 32^{\prime} \mathrm{S}, 49^{\circ} 10^{\prime} \mathrm{E}$, is a mountain range running north-south at the extreme northern tip of Madagascar (Fig. 1). It is also referred to as Ambohitra on modern Madagascan maps, and as Amber Mountain on English maps of the last century, but these names are rarely used. The highest peak is at $1475 \mathrm{~m}$ altitude, with the foot of the mountain range at 200-300 m. Montagne d'Ambre has a distinctive microclimate. The annual precipitation (e.g. Station Roussettes, mean $2378 \mathrm{~mm}$ ) is much higher than the surrounding region (e.g. Antsiranana, mean $980 \mathrm{~mm}$ ) (Nicoll \& Langrand, 1989).
The vegetation of Montagne d'Ambre is rainforest, with moist montane forest above $800 \mathrm{~m}$ and lowland rainforest below $800 \mathrm{~m}$ (vegetation types of White, 1983). The forest below $800 \mathrm{~m}$ appears to be transitional in form to the surrounding much drier deciduous forests which are at $0-300 \mathrm{~m}$ elevation. Montagne d'Ambre rainforest is completely isolated from the major rainforest block of the north and east. The $110 \mathrm{~km}$ of arid habitats which separate Montagne d'Ambre rainforest from the closest rainforests at Ambanja have not been produced by recent human activity. The Montagne d'Ambre Massif is volcanic in origin, composed of basaltic rock formed about $14 \mathrm{M}$ years ago (IUCN/ UNEP/WWF, 1987); therefore it is possible that the Montagne d'Ambre rainforest may have been isolated for millions of years.

The Montagne d'Ambre forests were first protected in the 1920 s as a forestry station ('Les Roussettes') established in rainforest at $1000 \mathrm{~m}$ altitude. The first $\mathrm{Na}$ tional Park in Madagascar was created at Montagne d'Ambre in 1958, with a surface area of 18200 ha. The Forêt d'Ambre Special Reserve (4810 ha) was created at the same time. These two protected areas include forest between 417 and $1474 \mathrm{~m}$ in elevation. During the development of the forestry station and later the $\mathrm{Na}$ tional Park exotic trees (e.g. Eucalyptus and pines) were introduced, two small dams built to feed an irrigation system, and about $30 \mathrm{~km}$ of roads and paths cut within the forest. All the Montagne d'Ambre forests are currently managed by the Direction des Eaux et Forêt and the World Wide Fund for Nature.

Despite the relatively old ages of the Park and Special Reserve and the interesting biogeographic history of Montagne d'Ambre, some of the vertebrate groups were still poorly known prior to this study. This was especially true for amphibians and reptiles. Specimens had been collected from the region for more than 100 years, with the earliest herpetological collection (deposited in the Paris National Museum in 1883) made by Alluaud and Belly. Typically, however, these specimens lack precise locality data, which is a significant problem because of the wide elevational range and diverse forest types found in the region. Species were often represented by a single specimen, which made it impossible to understand character variation within local populations and increased the risk of taxonomic errors. 


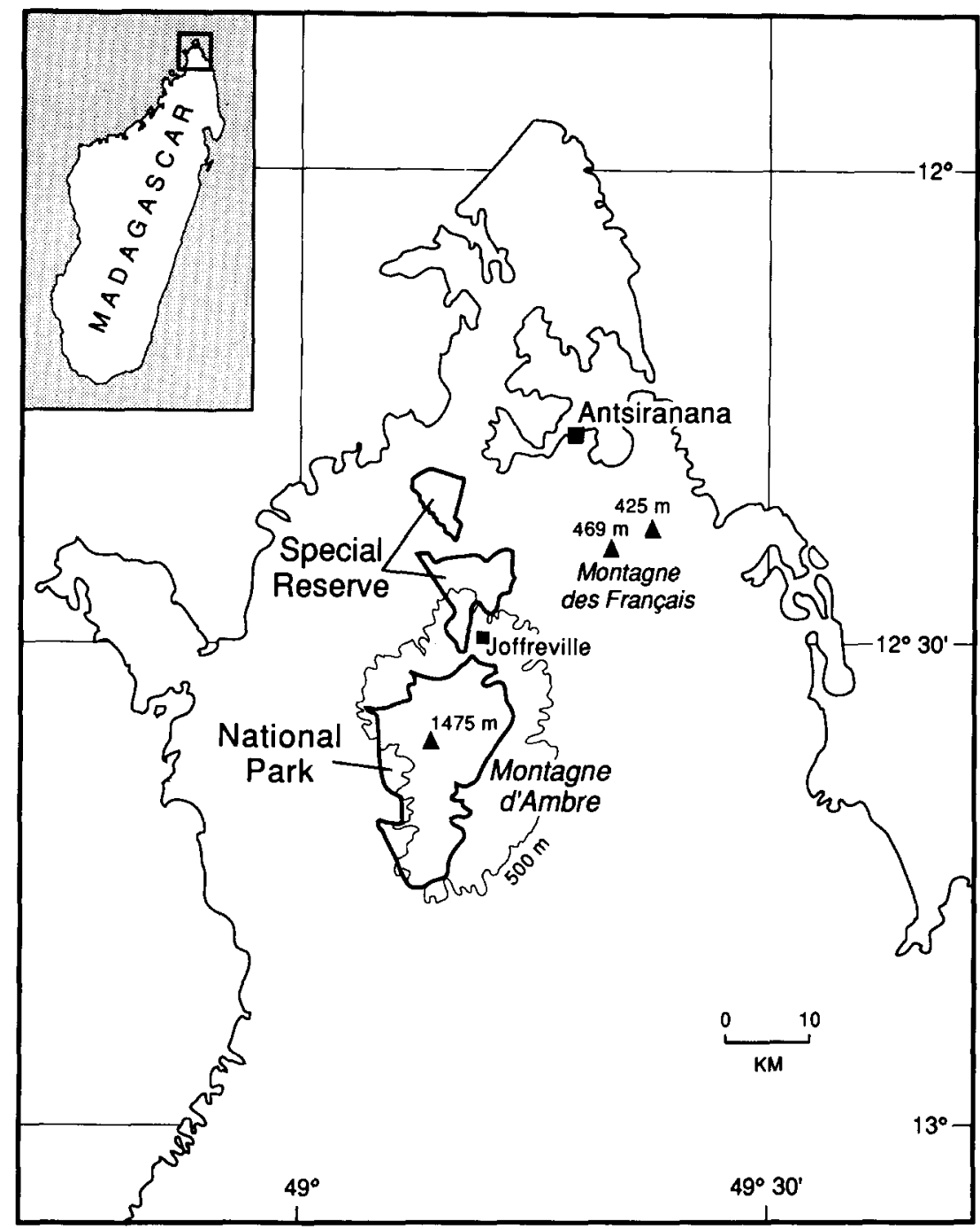

Fig. 1. Map showing locations of study sites.

By 1989 two vertebrate species lists had been published for Montagne d'Ambre by conservation organisations, which listed seven frog, 16 reptile, and five small mammal species (IUCN/UNEP/WWF, 1987; Nicoll \& Langrand, 1989). Of these, four reptile and one mammal species were known only from this region. However, because of the scattered literature, some published records inevitably were omitted from these lists.

The results of prior herpetological surveys made by us at other rainforest sites in Madagascar suggested that many more amphibians and reptiles would be found at Montagne d'Ambre. Therefore, because of the biogeographic importance of the region and the lack of adequate information, a survey of amphibians, reptiles, and small mammals was undertaken in 1991-92.

\section{LITERATURE SUMMARY}

The amphibian, reptile, and small mammal species recorded in the literature from Montagne d'Ambre are shown in Table 1. We included only records which specifically state 'Montagne d'Ambre' 'Mararaomby', 'Roussettes', 'Ambohitra' and 'Joffreville'. These sites are all within the Montagne d'Ambre mountain range, and may refer to the National Park, Special Reserve, the entire mountain range, or, for the last locality, the town at $12^{\circ} 30^{\prime} \mathrm{S}, 49^{\circ} 12^{\prime} \mathrm{E}$. We did not include records for the Antsiranana (Diego Suarez) region because of the very different habitats included in this vague locality. The Antsiranana region could refer to either Antsiranana town, the mostly degraded dry forests which surround Antsiranana, the limestone mountains of Montagne de Francais (10 km southeast of Antsiranana), or Montagne d'Ambre (40 km southwest of Antsiranana). Montagne d'Ambre was consistently used as a collecting locality since the end of the last century, therefore we do not think Montagne d'Ambre was normally included by collectors in the Antsiranana region locality.

The following sources provided Montagne d'Ambre specimen records: frogs (Blommers-Schlösser \& Blanc, 1991), Lygodactylus (Pasteur \& Blanc, 1967), Paroedura (Angel, 1942), Uroplatus (Bauer \& Russell, 1989), Phelsuma (Loveridge, 1942; Mertens, 1964), chameleons (Brygoo, 1971, 1978), Androngo (Brygoo, 1981), Amphiglossus (Brygoo, 1984), Paracontias (Brygoo, 1980), Zonosaurus (Brygoo \& Boehme, 1985), snakes (Guibé, 1958), Microgale (MacPhee, 1987), and Eliurus (Carlton \& Schmidt, 1990). In only a few cases (amphibians and reptile specimens held at the National Museum, 
Table 1. Amphibian, reptile and small mammal species recorded at Montagne d'Ambre

\begin{tabular}{|c|c|c|c|c|c|}
\hline \multirow[t]{2}{*}{ Species } & \multicolumn{2}{|c|}{ Collected specimens } & \multirow{2}{*}{$\begin{array}{l}\text { Altitude } \\
\text { (m) }\end{array}$} & \multicolumn{2}{|c|}{ Habitat } \\
\hline & Literature & 1991-92 survey & & Forest & Non-forest \\
\hline \multicolumn{6}{|l|}{ AMPHIBIA } \\
\hline \multicolumn{6}{|l|}{ Microhylidae } \\
\hline Stumpffia psologlossa & $*$ & $*$ & $600-1250$ & $*$ & \\
\hline Stumpffia c.f. grandis & & $*$ & 650 & * & \\
\hline Plethodontohyla laevipes & $*$ & $*$ & $900-1200$ & $*$ & \\
\hline Plethodontohyla sp. nov. 1 & & * & 650 & $*$ & \\
\hline Plethodontohyla sp. nov. 2 & & * & 650 & $*$ & \\
\hline Plethodontohyla sp. nov. 3 & & * & 650 & $*$ & \\
\hline Cophyla phyllodactyla & $*$ & $*$ & $1100-1250$ & $*$ & \\
\hline Platypelis grandis & & $*$ & 650 & $*$ & \\
\hline \multicolumn{6}{|l|}{ Ranidae } \\
\hline Ptychadena mascareniensis & $*$ & $*$ & $900-1200$ & & $*$ \\
\hline \multicolumn{6}{|l|}{ Mantellidae } \\
\hline Laurentomantis horrida & & * & 1200 & $*$ & \\
\hline Mantidactylus granulatus & $*$ & $*$ & $900-1250$ & $*$ & \\
\hline Mantidactylus curtus & $*$ & $*$ & $650-1150$ & $*$ & \\
\hline Mantidactylus wittei & & $*$ & 900 & * & \\
\hline Mantidactylus femoralis & $*$ & $*$ & $650-1150$ & * & \\
\hline Mantidactylus liber & & $*$ & 1150 & * & \\
\hline Mantidactylus ambreensis & & $*$ & $650-1150$ & * & \\
\hline Mantidactylus asper & & $*$ & $900-1250$ & $*$ & \\
\hline Mantidactylus pseudoasper & & $*$ & $600-900$ & * & \\
\hline Mantidactylus bicalcaratus & & * & $950-1200$ & * & \\
\hline \multicolumn{6}{|l|}{ Rhacophoridae } \\
\hline Aglyptodactylus madagascariensis & $*$ & * & $900-1200$ & * & \\
\hline Boophis luteus & & * & $650-1150$ & * & \\
\hline Boophis madagascariensis & $*$ & * & $650-1200$ & * & \\
\hline Boophis miniatus & & * & $650-1150$ & * & \\
\hline Boophis untersteini & & * & $750-950$ & * & \\
\hline \multicolumn{6}{|l|}{ REPTILIA } \\
\hline \multicolumn{6}{|l|}{ Gekkonidae } \\
\hline Ebenavia inunguis & & * & 650 & * & \\
\hline Geckolepis maculata & & * & 650 & * & \\
\hline Lygodactylus madagascariensis & * & * & $650-1200$ & * & \\
\hline Phelsuma lineata & * & * & $650-1100$ & * & * \\
\hline Phelsuma madagascariensis & * & $*$ & $800-900$ & * & * \\
\hline Paroedura oviceps & & $*$ & 650 & * & \\
\hline Paroedura stumpffi & * & * & 650 & * & \\
\hline Uroplatus alluaudi & * & $*$ & $650-950$ & * & \\
\hline Uroplatus ebenaui & * & $*$ & $650-1200$ & $*$ & \\
\hline Uroplatus fimbriatus & * & $*$ & $650-800$ & $*$ & \\
\hline Uroplatus sikorae & & $*$ & $650-950$ & $*$ & \\
\hline \multicolumn{6}{|l|}{ Chamaeleonidae } \\
\hline Brookesia ebenaui & * & $*$ & $650-800$ & * & \\
\hline Brookesia stumpffi & * & $*$ & $650-1200$ & $*$ & \\
\hline Brookesia tuberculata & * & $*$ & 900 & * & \\
\hline Brookesia sp. nov. 1 & & * & $650-1200$ & $*$ & \\
\hline Brookesia sp. nov. 2 & & * & 650 & * & \\
\hline Calumma boettgeri & * & $*$ & $650-1250$ & $*$ & \\
\hline Calumma brevicornis & $*$ & * & $900-1300$ & $*$ & \\
\hline Calumma nasuta & * & * & 900 & & * \\
\hline Calumma oshaughnessyi & $*$ & $*$ & $900-1250$ & * & \\
\hline Furcifer pardalis & * & * & $650-900$ & * & * \\
\hline Furcifer petteri & $*$ & $*$ & $650-700$ & $*$ & * \\
\hline \multicolumn{6}{|l|}{ Scincidae } \\
\hline Androngo alluaudi & $*$ & & $?$ & $?$ & $?$ \\
\hline Amphiglossus melanopleura & & $*$ & $900-1250$ & * & \\
\hline Amphiglossus melanurus & & $*$ & 1100 & * & \\
\hline Amphiglossus mouroundavae & $*$ & $*$ & $900-1250$ & * & \\
\hline Amphiglossus stumpffi & & $*$ & 650 & * & \\
\hline Mabuya elegans & & $*$ & $600-850$ & & * \\
\hline Paracontias brocchii & $*$ & $*$ & $900-1250$ & * & \\
\hline Paracontias hildebrandti & & $*$ & $600-700$ & * & \\
\hline
\end{tabular}


Table 1 - contd.

\begin{tabular}{|c|c|c|c|c|c|}
\hline \multirow[t]{2}{*}{ Species } & \multicolumn{2}{|c|}{ Collected specimens } & \multirow{2}{*}{$\begin{array}{l}\text { Altitude } \\
\text { (m) }\end{array}$} & \multicolumn{2}{|c|}{ Habitat } \\
\hline & Literature & 1991-92 survey & & Forest & Non-forest \\
\hline \multicolumn{6}{|l|}{ REPTILIA - contd. } \\
\hline \multicolumn{6}{|l|}{ Cordylidae } \\
\hline Zonosaurus haroldmeieri & * & * & $700-1000$ & & $*$ \\
\hline \multicolumn{6}{|l|}{ Typhlopidae } \\
\hline Typhlops c.f. mucronatus & & $*$ & 650 & * & \\
\hline Typhlops microcephalus & & $*$ & $650-1200$ & * & \\
\hline \multicolumn{6}{|l|}{ Boidae } \\
\hline Boa manditra & * & * & $650-950$ & & \\
\hline \multicolumn{6}{|l|}{ Colubridae } \\
\hline Alluaudina bellyi & * & * & 650 & * & \\
\hline Geodipsas heimi & & $*$ & $900-1250$ & $*$ & \\
\hline Geodipsas infralineata & & * & 650 & * & \\
\hline Leioheterodon madagascariensis & * & * & $650-1000$ & * & * \\
\hline Liophidium rhodogaster & $*$ & $*$ & $850-1150$ & * & \\
\hline Liophidium torquatus & & $*$ & $900-950$ & * & * \\
\hline Liophidium sp. nov. & & * & 650 & $*$ & \\
\hline Liopholidophis lateralis & & $*$ & $600-900$ & $*$ & * \\
\hline Liopholidophis sp. nov. & & $*$ & $900-1250$ & * & \\
\hline Lycodryas arctifasciatus & & * & $650-850$ & $*$ & \\
\hline Pararhadinaea albignaci & & * & 650 & * & \\
\hline Pseudoxyrhopus ambreensis & $*$ & $*$ & $900-1200$ & $*$ & \\
\hline Pseudoxyrhopus microps & & $*$ & 650 & $*$ & \\
\hline \multicolumn{6}{|l|}{ MAMMALIA } \\
\hline \multicolumn{6}{|l|}{ Tenrecidae } \\
\hline Microgale brevicaudata & & * & $650-670$ & * & \\
\hline Microgale longicaudata & & $*$ & $650-1250$ & * & \\
\hline Microgale melanorrhachis & & $*$ & $1125-1250$ & * & \\
\hline Microgale parvula & * & * & 1125 & * & \\
\hline Microgale talazaci & & * & $660-1250$ & * & \\
\hline Microgale sp. & & $*$ & $650-1250$ & $*$ & \\
\hline Tenrec ecaudatus & $*$ & $*$ & $650-1150$ & $*$ & \\
\hline Setifer setosus & $*$ & * & $650-660$ & * & \\
\hline \multicolumn{6}{|l|}{ Soricidae } \\
\hline Suncus murinus & & $*$ & 1150 & $*$ & \\
\hline \multicolumn{6}{|l|}{ Murideae } \\
\hline Eliurus myoxinus majori & * & * & $1150-1200$ & * & \\
\hline Eliurus myoxinus webbi & * & * & $650-700$ & * & \\
\hline Rattus rattus & $*$ & * & $650-1125$ & $*$ & \\
\hline
\end{tabular}

Paris) were we able to examine museum material to confirm identifications.

IUCN/UNEP/WWF (1987) and Nicoll and Langrand (1989) listed other herpetological species for Montagne d'Ambre for which we are unable to find documentary support (museum specimens or literature descriptions). We suspect Boa manditra (formerly Sanzinia madagascariensis, see Kluge, 1991) and Liophidium rhodogaster are personal observations, Mantidactylus lugubris is a misidentification (probably of $M$. femoralis or $M$. ambreensis), while Homopholis boivini, Amphiglossus ardouini, Boa madagascariensis (formerly Acrantophis madagascariensis, see Kluge, 1991), and Ithycyphus miniatus are all literature records for Antsiranana. Two other listed species have subsequently been synonymized: Mantidactylus flavicrus is a synonym of $M$. femoralis (Blommers-Schlösser \& Blanc, 1991), and Microgale prolixacaudata a synonym of $M$. cowani (MacPhee, 1987).

Blommers-Schlösser and Blanc (1991) gave Montagne d'Ambre localities (Montagne d'Ambre, Mararaomby or Les Roussettes) for several frog species which we found were misidentified at the Muséum national d'Histoire naturelle, Paris (see Table 2). Boophis goudoti is also recorded from Montagne d'Ambre by Blommers-Schlösser and Blanc (1991), but we found neither voucher specimens nor records at Paris and suspect this species does not exist at Montagne d'Ambre.

\section{STUDY SITES}

Fieldwork was centered at two field camps located within primary forest, which facilitated exploration of the full altitudinal range found within the Park (Fig 1). Camp 1, Antomboka River, $12^{\circ} 32.22^{\prime} \mathrm{S}, 4^{\circ} 10.05^{\prime} \mathrm{E}$, $1150 \mathrm{~m}$ altitude in cloud forest, was occupied from 15 November 1991 to 15 December 1991. During this period the typical forest altitude surveyed was $900-1450$ m. Camp 2, Antomboka River Fitsahana, 12 29.33 'S, $49^{\circ} 10.28^{\prime} \mathrm{E}, 650 \mathrm{~m}$ altitude in lowland rainforest with transition to drier deciduous forest, was occupied from 21 December 1991 to 20 January 1992. During this period the typical forest altitude surveyed was $600-950 \mathrm{~m}$. 
Table 2. New identifications of Montagne d'Ambre amphibians in the National Museum, Paris

\begin{tabular}{llll}
\hline $\begin{array}{l}\text { Museum number } \\
\text { MNHP }\end{array}$ & Family & Species identification \\
\hline $1975.2469-70$ & Rhacophoridae & Boophis miniatus & Poophis majori \\
$1975.322,324-5$ & Mantellidae & Mantidactylus asper & $\begin{array}{l}\text { Mantidactylus luteus } \\
1975.329\end{array}$ \\
$1975.585-6,588$, & Mantellidae & Mantidactylus asper & Mantidactylus luteus \\
$1975.592-3,596,599$ & Mantellidae & Mantidactylus curtus & Mantidactylus ulcerosus \\
$1975.607,613-5$ & Mantellidae & Mantidactylus curtus & Mantidactylus ulcerosus \\
$1975.587,590,596$ & Mantellidae & Mantidactylus curtus & Mantidactylus ulcerosus \\
\hline
\end{tabular}

\section{MATERIALS AND METHODS}

The survey was timed for the onset of the rainy season when most species are breeding and, therefore, activity is at its highest. Field techniques used to sample animals were (1) pitfall trapping with drift fences; (2) opportunistic day and night searching; (3) refuge examination (under and in fallen logs; under bark; and in leaf litter, soil and talus, and leaf axils of screw palms Pandanus and traveller's palm Ravenala).

The pitfall traps were buckets $(275 \mathrm{~mm}$ deep, 290 $\mathrm{mm}$ top internal diameter, $220 \mathrm{~mm}$ bottom internal diameter), sunk in the ground at intervals along a $100-\mathrm{m}$ drift fence. The handles of the buckets were removed, and small holes ( $2 \mathrm{~mm}$ diameter) were punched in the bottom to allow water to drain. The fence $(0.5 \mathrm{~m} \mathrm{high})$ was made from plastic sheeting stapled to thin wooden stakes. The fence bottom was buried $50 \mathrm{~mm}$ deep into the ground using leaf litter and positioned to run across the middle of each pitfall trap. A pitfall trap was positioned at both ends of the drift fence, with the other nine traps at $10-\mathrm{m}$ intervals. The trap lines were checked each morning and pitfall captures removed from the lines, except in the case of live mammals, which were uniquely marked (by fur clipping) and released at the point of capture. Four lines were used at a time, and sampling was made over 11-16 days. A total of 16 lines were erected during the survey.

Opportunistic searching and refuge examination were made throughout the full elevation range of habitats available at Montagne d'Ambre. The majority of searching was done close to existing trails, although ridges and river banks were also used to orientate search paths. Night searches were made using a head-lamp.

The following information was recorded at the time of capture for each specimen: date, time, longitude and latitude, altitude, microhabitat, and circumstances of capture. Liver and muscle were removed from representatives of almost all species and frozen in liquid nitrogen. A photographic record was made of representative live individuals of all species. Frog calls were recorded for those species found breeding. Specimens were fixed in $10 \%$ buffered formalin and later transferred to alcohol. Collected material was deposited at three main centers: the Museum of Zoology, University of Michigan; the Zoology Department, University of Antana- narivo; and the Zoology Section, Tsimbazaza Park, Antananarivo.

We followed the most recently published taxonomic revisions, except that we continue to recognise Mantidactylus ambreensis Mocquard 1895 (synonymised with M. femoralis by Guibé, 1978) and Microgale melanorrhachis Morrison-Scott 1948 (synonymised with $M$. cowani by MacPhee, 1987).

We recently examined the Mantidactylus ambreensis holotype (MHNP 1893.241), which has a distinct lateral border between the dark dorsal and pale ventral coloration on the flanks. Mantidactylus femoralis has a poorly defined border which is usually marbled. Both species were found to be sympatric at Montagne

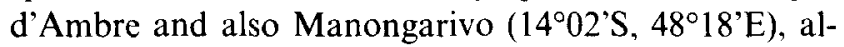
though $M$. femoralis was rarer. A more detailed diagnosis of $M$. ambreensis will be published elsewhere.

Microgale melanorrhachis was synonymised with $M$. cowani by MacPhee (1987) because of similar dentition. He considered the black dorsal vertebral stripe used to diagnose $M$. melanorrhachis as a polymorphic trait of $M$. cowani. We found that striped individuals have a much paler ventral coloration and are slightly smaller than unstriped individuals at Mantady National Park ( $18^{\circ} 51^{\prime} \mathrm{S}, 48^{\circ} 27^{\prime} \mathrm{E}$ ), and conclude that these two forms are good species. Pitfall trap data from Mantady suggests that at $1100 \mathrm{~m}$ elevation $M$. melanorrhachis is restricted to valley bottoms, whereas $M$. cowani is found in valley bottoms, on slopes and in ridge forest. We found the two species sympatric at Ambatovaky Special Reserve (16 $51^{\circ} \mathrm{S}, 49^{\circ} 08^{\prime} \mathrm{E}$ ), but only $M$. cowani in the Tölanaro region (e.g. $24^{\circ} 34^{\prime}$ S, $46^{\circ} 49^{\prime} \mathrm{E}$ ), and only $M$. melanorrhachis at Montagne d'Ambre and Manongarivo.

\section{RESULTS}

A total of 24 amphibian, 46 reptile and 12 small mammal species were recorded within Montagne d'Ambre National Park and Special Reserve. A complete species list is given in Table 1 along with the altitudinal range for each species and their occurrence in primary and/or secondary forests. The majority of data used to compile Table 1 was provided by collecting specimens through opportunistic searching and refuge examination. Three amphibian, four reptile and possibly one mammal 
Table 3. Montagne d'Ambre pitfall lines used to capture amphibians, reptiles and small mammals (capture rate \% is number of vertebrate individuals captured per trap day)

\begin{tabular}{|c|c|c|c|c|c|c|c|c|}
\hline Line & $\begin{array}{c}\text { Forest } \\
\text { Type }\end{array}$ & Latitude & Longitude & $\begin{array}{l}\text { Altitude } \\
\text { (m) }\end{array}$ & $\begin{array}{l}\text { Start } \\
\text { Date }\end{array}$ & Days & $\begin{array}{l}\text { Trap } \\
\text { Days }\end{array}$ & $\begin{array}{c}\text { Capture rate } \\
(\%)\end{array}$ \\
\hline I & Valley & $12^{\circ} 32 \cdot 17^{\prime} \mathrm{S}$ & $49^{\circ} 10 \cdot 12^{\prime} \mathrm{E}$ & 1125 & 19.11 .91 & 16 & 176 & $6 \cdot 3$ \\
\hline 2 & Slope & $12^{\circ} 32 \cdot 17 \mathrm{~S}$ & $49^{\circ} 09 \cdot 88^{\prime} \mathrm{E}$ & 1125 & 20.11 .91 & 15 & 165 & $13 \cdot 3$ \\
\hline 3 & Ridge & $12^{\circ} 32 \cdot 22^{\prime} \mathrm{S}$ & $49^{\circ} 10 \cdot 17^{\prime} \mathrm{E}$ & 1150 & 19.11 .91 & 16 & 176 & $30 \cdot 0$ \\
\hline 4 & Valley & $12^{\circ} 32 \cdot 22^{\prime} \mathrm{S}$ & $49^{\circ} 10 \cdot 10^{\prime} \mathrm{E}$ & 1125 & 21.11 .91 & 14 & 154 & 14.9 \\
\hline 5 & Ridge & $12^{\circ} 32 \cdot 33 ' \mathrm{~S}$ & $49^{\circ} 10^{-22} \mathrm{E}$ & 1150 & 5.12 .91 & 11 & 121 & $47 \cdot 8$ \\
\hline 6 & Ridge & $12^{\circ} 32 \cdot 38^{\prime} \mathrm{S}$ & $49^{\circ} 10 \cdot 00^{\prime} \mathrm{E}$ & 1150 & 5.12 .91 & 11 & 121 & $31 \cdot 4$ \\
\hline 7 & Ridge & $12^{\circ} 32 \cdot 78 \mathrm{~S}$ & $49^{\circ} 09 \cdot 68^{\prime} \mathrm{E}$ & 1250 & 5.12 .91 & 11 & 121 & $52 \cdot 1$ \\
\hline 8 & Ridge & $12^{\circ} 32 \cdot 62^{\prime} \mathrm{S}$ & $49^{\circ} 10 \cdot 00^{\prime} \mathrm{E}$ & 1125 & 6.12 .91 & 11 & 121 & $53 \cdot 7$ \\
\hline 9 & Slope & $12^{\circ} 29 \cdot 33^{\prime} \mathrm{S}$ & $49^{\circ} 10 \cdot 33^{\prime} \mathrm{E}$ & 660 & 26.12 .91 & 13 & 143 & 11.9 \\
\hline 10 & Valley & $12^{\circ} 29 \cdot 20^{\prime} S$ & $49^{\circ} 10 \cdot 28^{\prime} \mathrm{E}$ & 650 & 26.12 .91 & 13 & 143 & 14.7 \\
\hline 11 & Valley & $12^{\circ} 29 \cdot 17^{\prime} \mathrm{S}$ & $49^{\circ} 10 \cdot 30^{\prime} \mathrm{E}$ & 650 & 26.12 .91 & 13 & 143 & $18 \cdot 2$ \\
\hline 12 & Valley & $12^{\circ} 29 \cdot 17 \mathrm{~S}$ & $49^{\circ} 10 \cdot 33^{\prime} \mathrm{E}$ & 650 & 26.12 .91 & 13 & 143 & 8.4 \\
\hline 13 & Slope & $12^{\circ} 29.05^{\prime} \mathrm{S}$ & $49^{\circ} 10^{\cdot} 22^{\prime} \mathrm{E}$ & 660 & 7.1 .92 & 12 & 132 & $2 \cdot 3$ \\
\hline 14 & Slope & $12^{\circ} 29 \cdot 00^{\prime} \mathrm{S}$ & $49^{\circ} 10 \cdot 17^{\prime} \mathrm{E}$ & 670 & 7.1 .92 & 12 & 132 & $19 \cdot 7$ \\
\hline 15 & Valley & $12^{\circ} 29 \cdot 00^{\prime} \mathrm{S}$ & 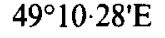 & 650 & 8.1 .92 & 12 & 132 & $10 \cdot 6$ \\
\hline 16 & Valley & $12^{\circ} 29 \cdot 12^{\prime} \mathrm{S}$ & $49^{\circ} 10 \cdot 22^{\prime} \mathrm{E}$ & 650 & 8.1 .92 & 11 & 121 & $26 \cdot 4$ \\
\hline
\end{tabular}

species are undescribed. Of the 82 species recorded during this survey, $42(51 \%)$ are new records for Montagne d'Ambre. Just three species were found only in secondary habitats, representing $4 \%$ of the total fauna, while 68 species $(83 \%)$ were found only in primary forest.

The pitfall trap lines are characterised in Table 3. A total of 484 vertebrates were captured over 2244 pitfall trap days, giving an overall vertebrate capture rate of $21.6 \%$ per trap day. The number of individuals of each species caught by the trap lines is summarized in Table 4. The pitfalls caught five amphibian, 10 reptile, and 11 mammal species.

Table 4. Pitfall trap capture of amphibians, reptiles and small mammals

\begin{tabular}{|c|c|c|c|c|c|c|c|c|c|c|c|c|c|c|c|c|}
\hline \multirow[t]{3}{*}{ Species } & \multicolumn{16}{|c|}{ Number of individuals captured } \\
\hline & \multicolumn{16}{|c|}{ Pitfall line number } \\
\hline & 1 & 2 & 3 & 4 & 5 & 6 & 7 & 8 & 9 & 10 & 11 & 12 & 13 & 14 & 15 & 16 \\
\hline \multicolumn{17}{|l|}{ AMPHIBIA } \\
\hline Aglyptodactylus madagascariensis & & 1 & & & & & & & & & & & & & & \\
\hline Laurentomantis horrida & & & & & & 1 & & 1 & & & & & & & & \\
\hline Plethodontohyla laevipes & & & 3 & & & & & 1 & & & & & & & & \\
\hline Plethodontohyla sp. nov. 2 & & & & & & & & & 1 & 1 & & & & 1 & 2 & 1 \\
\hline Stumpffia psologlossa & 2 & 1 & 3 & 4 & & 3 & 1 & 2 & 6 & 10 & 18 & 2 & 1 & 18 & 2 & 21 \\
\hline \multicolumn{17}{|l|}{ REPTILIA } \\
\hline Amphiglossus melanopleura & 1 & & & & & 7 & & 2 & & & & & & & & \\
\hline Amphiglossus mouroundavae & 1 & & 3 & 1 & 6 & 5 & 1 & 8 & & & & & & & & \\
\hline Amphiglossus stumpffi & & & & & & & & & 1 & 2 & 1 & 5 & 1 & 1 & 4 & 2 \\
\hline Brookesia stumpffi & & & & & & & & & & & & & & 1 & & \\
\hline Brookesia sp. nov. 1 & & & & & & & & & & 1 & & & & & & \\
\hline Paracontias brocchi & & 1 & & & & & & & & & & & & & & \\
\hline Pararhadinaea albignaci & & & & & & & & & & & & 1 & & 1 & & \\
\hline Paroedura oviceps & & & & & & & & & 1 & 1 & 1 & 1 & & & & \\
\hline Paroedura stumpffi & & & & & & & & & & & & & & 1 & & 2 \\
\hline Typhlops microcephalus & & & 2 & & & & & & & & & & & & & \\
\hline \multicolumn{17}{|l|}{ MAMMALIA } \\
\hline Eliurus myoxinus majori & & & & 2 & & 1 & & & & & & & & & & \\
\hline Eliurus myoxinus webbi & & & & & & & & & & 1 & & & & & & \\
\hline Microgale brevicaudata & & & & & & & & & 2 & 3 & 1 & 2 & & 1 & 2 & 2 \\
\hline Microgale longicaudata & & & 3 & & 15 & & 4 & 10 & 1 & 1 & 1 & 1 & & & & 1 \\
\hline Microgale melannorhachis & 9 & 18 & 33 & 12 & 36 & 17 & 52 & 38 & & & & & & & & \\
\hline Microgale parvula & & & & 1 & & & & 1 & & & & & & & & \\
\hline Microgale talazaci & 3 & & 5 & 3 & & 4 & 4 & 2 & 3 & & & & & & & \\
\hline Microgale sp. 1 & & & 1 & & & & 1 & & & 1 & 3 & & 2 & 2 & 4 & 2 \\
\hline Rattus rattus & & & & & & & & 1 & & & & & & & & \\
\hline Setifer setosus & & & & & & & & & 1 & & 1 & & & & & 2 \\
\hline Suncus murinus & & 2 & & & 1 & & & & & & & & & & & \\
\hline
\end{tabular}




\section{DISCUSSION}

\section{Previous studies}

Less than half of the species we found at Montagne d'Ambre had been previously reported in the literature from this locality but there was almost no information on their altitude or habitat distributions within the massif. Our survey results were perhaps unexpected because Montagne d'Ambre is considered as one of the most intensively studied rainforest regions of Madagascar, having been visited by collectors for more than 100 years. According to Nicoll and Langrand (1989), just six rainforest sites (Andringitra, Lokobe, Marojejy, Manongarivo, Analamazaotra and Ambohitantely) had more known herpetological species.

Although for most sites in Madagascar there is very little published herpetological information, even less is readily available to conservation organisations. The scattered nature of the literature (often in specialist publications) has meant that previously compiled herpetological species lists have many omissions. In the case of Montagne d'Ambre, this has meant that the herpetological species lists published by IUCN/ UNEP/WWF (1987) and Nicoll and Langrand (1989) omitted five amphibian and 12 reptile species.

Errors in the literature, either misidentifications or incorrect localities, were also prevalent. The frog distribution maps of Blommers-Schlösser and Blanc (1991) appear to be based in part on museum material which was not critically examined. Of the 12 species shown on their maps in Montagne d'Ambre, four apparently were misidentified (see earlier), giving a 33\% error. Of the 23 herpetological species listed for Montagne d Ambre in IUCN/UNEP/WWF (1987) and Nicoll and Langrand (1989) six probably do not occur at the site (see earlier) giving a $26 \%$ error.

We found errors of similar magnitude during a detailed herpetological study in the Tölanaro (Fort Dauphin) region, in southeastern Madagascar. Specimens were misidentified and localities frequently vague and sometimes obviously incorrect. For example, of the 13 amphibian species reported by Blommers-Schlösser and Blanc (1991) from Fort Dauphin, Ste Luce and Mandena, four species (Heterixalus tricolor, Mantidactylus boulengeri, $M$. liber, and Aglyptodactylus madagascariensis) have obviously been misidentified or have incorrect localities, giving a $31 \%$ error. Furthermore, earlier collectors used the 'Fort Dauphin' locality to describe many different sites in the region. This is a significant problem because the region includes three completely different habitats: primary rainforest, semiarid littoral forest, and semi-arid spiny forest. As a result, the habitat and precise locality of each specimen are unknown.

If Montagne d'Ambre and Tölanaro are representative, then the literature contains $26-40 \%$ errors (from incorrect localities and misidentifications). In addition the lack of detailed survey data means that most species lists accurately describe just a small fraction of the actual herpetological species diversity. For Montagne
d'Ambre, $20 \%$ of the herpetofauna was accurately described by IUCN/UNEP/WWF (1987) and Nicoll and Langrand (1989) and $27 \%$ of the amphibian fauna by Blommers-Schlösser and Blanc (1991). Disturbingly, both sources are currently being used to determining amphibian and reptile conservation priorities in Madagascar.

\section{Habitat and distribution}

Of the 82 species recorded in this survey, $68(83 \%)$ were found only in primary forest. Only four species were found just in non-forest habitats: a ranid frog Ptychadena mascareniensis in a crater lake at $1200 \mathrm{~m}$ altitude; a chameleon Calumma nasuta in a pine plantation; a skink Mabuya elegans and a plated lizard Zonosaurus haroldmeieri on grassy road banks and in clearings. The other 77 species were all found within primary rainforest. Clearly, most species included in our survey are dependent on primary rainforest habitat and do not do well in degraded or open habitats. This strongly reaffirms the belief that the native forest of Montagne d'Ambre must be conserved to maintain high levels of biodiversity in this region of Madagascar.

The altitudinal distributions of the amphibians, reptiles, and small mammals is restricted in most cases to just a portion of the full altitudinal range found at Montagne d'Ambre. A distinct transitional altitude was found for many species at $900 \mathrm{~m}$. Of the 82 species recorded, 30 were found exclusively at or below $900 \mathrm{~m}$ and 27 exclusively at or above $900 \mathrm{~m}$ altitude. A minority of the Montagne d'Ambre species $(30 \%)$ were found both above and below $900 \mathrm{~m}$. The $900 \mathrm{~m}$ contour corresponds closely to the transition between lowland rainforest and moist montane forest, which is indicated by White (1983) to be about $800 \mathrm{~m}$. The fauna of Montagne d'Ambre, therefore, appears to be largely composed of both lowland rainforest and moist montane forest specialists.

Some of the Montagne d'Ambre amphibians, reptiles, and small mammals are probably endemic to this mountain range. The following species are known only from Montagne d'Ambre: two microhylid toadsPlethodontohyla sp. nov. 2 and Plethodontohyla sp. nov. 3; two dwarf chameleons-Brookesia sp. nov. 1 and Brookesia sp. nov. 2; a skink-Paracontias brocchii; a plated lizard-Zonosaurus haroldmeieri; two colubrid snakes-Liopholidophis sp. nov. and Pseudoxyrhopus ambreensis; and a tenrec shrew-Microgale parvula. Pseudoxyrhopus ambreensis and Microgale parvula were known previously only by their holotypes (Guibé, 1958; MacPhee, 1987), and Paracontias brocchii by three specimens (Brygoo, 1980). The Montagne d'Ambre rainforest, isolated by $110 \mathrm{~km}$ from the once continuous rainforest belt of northern and eastern Madagascar, may have preserved relict populations of species that disappeared from other regions of the rainforest; or it may have facilitated speciation through geographic isolation. Both of these factors would produce endemics in the Montagne d'Ambre biota.

Some of the other species we found at Montagne 
d'Ambre are extremely rare in collections. The leaftailed gecko Uroplatus alluaudiwas previously known from just four specimens, two from Montagne d'Ambre and two from Imotra, the latter being an unknown locality in southcentral Madagascar (Bauer \& Russell, 1989). The colubrid snake Pararhadinaea albignaci was previously known only from a roadkill holotype collected at Analamazaotra (Perinet), 18 $57^{\circ} \mathrm{S}$, 4826'E, East Madagascar (Domergue, 1984). Both these species have potentially large geographic ranges, but appear to be difficult to find. At Montagne d'Ambre, three Uroplatus alluaudi and two Pararhadinaea albignaci were collected over a period of two months. Another rare species with a potentially large range is the microhylid toad Plethodontohyla sp. nov. 1, which we collected at Ambatovaky Special Reserve, $16^{\circ} 51^{\prime} \mathrm{S}, 4^{\circ} 25^{\prime} \mathrm{E}$, and Ranomafana National Park, $21^{\circ} 17^{\prime} \mathrm{S}, 47^{\circ} 26^{\prime} \mathrm{E}$, as well as at Montagne d'Ambre.

We found many of the Montagne d'Ambre species also at Manongarivo Special Reserve, $14^{\circ} 03^{\prime} \mathrm{S}, 4^{\circ} 20^{\prime} \mathrm{E}$, and some Montagne d'Ambre species are also recorded from Lokobe Reserve on Nosy Be Island. This northwestern rainforested region of Madagascar (not including Montagne d'Ambre) is sometimes referred to as the Sambirano Region and is floristically distinct from other regions of Madagascar (Humbert, 1955). The following Montagne d'Ambre species appear to be otherwise restricted to the Sambirano Region: frogs-Cophyla phyllodactyla, Mantidactylus ambreensis; geckos-Lygodactylus madagascariensis, Paroedura oviceps, Paroedura stumpff; chameleons-Brookesia ebenaui, Furcifer petteri; skinks-Androngo alluaudi, Amphiglossus mouroundavae, A. stumpffi; and snakes-Liophidium sp. nov. For all species in which it was determined at Montagne d'Ambre, it was very similar to that found at Manongarivo. Despite the disjunct distributions of these Sambirano species, they appear to be ecologically and morphologically similar to the Montagne d'Ambre populations.

Almost all of the Montagne d'Ambre amphibian and reptile species $(96 \%)$ are endemic to Madagascar, with just three species - a frog Ptychadena mascareniensis, a gecko Phelsuma madagascariensis and a snake Leioheterodon madagascariensis-occurring on other Indian Ocean Islands. For the small mammals $75 \%$ of the Montagne d'Ambre species are endemic to Madagascar (non endemics-Suncus murinus, Rattus rattus and Tenrec ecaudatus (introduced to Seychelles)). The extremely high level of endemicity seen in the fauna, at both the regional or national level, emphasizes the importance of the Montagne d'Ambre protected areas.

\section{Introductions}

Several of the species at Montagne d'Ambre may have been accidentally introduced. A single chameleon, Calumma nasuta, was found in pine forest close to the forestry station. All the small Calumma found in the native forests were $C$. boettgeri (probably more than 1000 were seen during the survey). At Manongarivo, in primary forest we found only $C$. boettgeri, and strongly suspect this species is naturally allopatric with $C$. nasuta in northern Madagascar. C. nasuta may have been accidentally introduced to Montagne d'Ambre when trees or other vegetation were transplanted to the gardens and plantations around the Roussettes forest station. Brygoo (1978) reported C. nasuta from Montagne d'Ambre and the islands of Nosy Be and Nosy Komba, although the circumstances of capture are not given. These may also be accidental introductions, because both islands are frequently visited by boats. We found C. nasuta in degraded habitats in southeastern Madagascar, indicating that it can establish itself in secondary habitats where we have never observed $C$. boettgeri.

Other possibly introduced species include the non-endemic ranid frog Ptychadena mascareniensis, which occurs at 'Cursed Lake' in Montagne d'Ambre. Carp were introduced to this and other crater lakes in the Park, and possibly tadpoles or eggs of $P$. mascareniensis were accidentally introduced at the same time. This frog was never found in primary forest, and 'Cursed Lake' is at least $6 \mathrm{~km}$ from the forest edge. The two small mammals Suncus murinus and Rattus rattus, both considered to have been introduced to Madagascar, were caught in primary forest and have obviously successfully invaded deeply into the Park. We also found both these species in primary rainforest at Manongarivo.

\section{Conservation}

Although Madagascar is regarded as one of the richest biological countries in the world it is also one of the most threatened. This is especially true for rainforest. Aerial photographs and satellite images show that between 1950 and $198550 \%$ of the remaining rainforest was destroyed (Green \& Sussman, 1990). The forests of Montagne d'Ambre are threatened by fire and clearing for cultivation (Nicoll \& Langrand, 1989), with most of this activity occurring at the periphery in the lower altitude forests. Comparing forest cover shown on 1:100000 maps published in the $1950-60$ s with current forest limits clearly shows that some peripheral forest has been lost over the past 30 years at Montagne d'Ambre, although the actual extent of forest has not yet been measured.

At Montagne d'Ambre the peripheral rainforests of the massif (which are most vulnerable to encroachment or degradation) are at a lower elevation and transitional in nature with respect to the surrounding much drier forest types. In this study we found $37 \%$ of the amphibians, reptiles and small mammals to be restricted to forest below $900 \mathrm{~m}$ altitude, and therefore largely confined to peripheral areas. A significant portion of the Montagne d'Ambre biodiversity is absent from the more sheltered core areas of the Park and Special Reserve. Deforestation, by fire or cultivation, at the edge of the reserves would eventually lead to the loss of some low-altitude species from the protected areas, and possibly even extinction of the low-altitude Montagne d'Ambre endemic frogs Plethodontohyla sp.nov. 1, Plethodontohyla sp. nov. 2 and the dwarf 
chameleon Brookesia sp. nov. 2. It is essential that the peripheral forests should be given high priority in future conservation initiatives-preserving an intact structural core of forest at the expense of peripheral forest will not maintain the region's existing biodiversity.

Accurate inventory studies are vital to understanding patterns of biodiversity both within and between protected areas. Factors limiting the distribution of species, such as altitude, rivers, and other natural boundaries, must all be considered when making management decisions for protected areas. In Madagascar, amphibians, reptiles and small mammals make ideal subjects for identifying patterns of biodiversity which can be applied to reserve management. These groups are typically speciesrich, highly adapted to specific native habitats, poor dispersers, and show a high degree of local endemicity.

Although species distribution patterns can have important consequences for reserve management it is vital that inventory data used for such purposes are known to be accurate and relatively complete. In Madagascar most published inventory lists of amphibians and reptiles contain a large degree of error and only report a small fraction of total species diversity. Accurate inventories are needed for all the protected areas of Madagascar to facilitate a comprehensive review of the reserve network's ability to maintain biodiversity.

The high diversity of amphibians, reptiles, and small mammals found at Montagne d'Ambre clearly demonstrates the importance of the Park and Special Reserve within the network of protected areas in Madagascar. Nine species are known only from Montagne d'Ambre, and possibly all nine may be endemic to this mountain range. Because of the high degree of local endemicity and the unique biogeographic isolation of the rainforests, the survival of an interesting and important component of the biodiversity of Madagascar depends on the successful conservation of the Montagne d'Ambre forests.

\section{ACKNOWLEDGEMENTS}

J. B. Ramanamanjato, A. Raselimanana, A. Razafimanantsoa and A. Razafimanantsoa made a substantial contribution to all aspects of the fieldwork over the full duration of the survey. We also thank B. Barnes, S. Biddle, J. Black, P. Brackett, L. Caira, I. Constable, A. Cooke, L. Embry, D. Green, J. Lee, J. Kaufmann, J. Kaufmann, U. Korneitchouk, S. Krauss, C. McKee, M. O'Dea, B. Power, A. Qualtrough, H. Richman, T. Stone, D. Standley, J. Stumper, D. Varey, D. Virden, G. Walsh and G. Zupansic for their help in field, and O. Langrand, M. Nicoll, S. O'Conner and F. Ravaoarimalala for supporting this project. We also wish to acknowledge the Ministère de l'Enseignement Supérieur, the Ministère de la Production Animale et des Eaux et Forêts and the Ministère de la Research Scientifique et Technologie pour le Developpement, whose support made this research program possible. This research was supported in part by a grant from the National Science Foundation (BSR-90-24505), World Wide Fund for Nature and Earthwatch.

\section{REFERENCES}

Angel, F. (1942). Les lézards de Madagascar. Mém. Acad. malgache, 36, 1-193.

Bauer, A.J. \& Russell, A.P. (1989). A systematic review of the genus Uroplatus (Reptilia: Gekkonidae), with comments on its biology. J. Nat. Hist., 23, 169-203.

Blommers-Schlösser, R.M.A. \& Blanc, C.P. (1991). Amphibiens (première partie). Faune de Madagascar, 75(1), 1-400.

Brygoo, E.R. (1971). Reptiles Sauriens Chamaeleonidae. Genre Chamaeleo. Faune de Madagascar, 33, 1-318.

Brygoo, E.R. (1978). Reptiles Sauriens Chamaleontidae. Genre Brookesia et complément pour le genre Chamaeleo. Faune de Madagascar, 47, 1-173.

Brygoo, E.R. (1980). Systématique des lézards scincidés de la région malgache, III. Les 'Acontias' de Madagascar. Pseudoacontias Barbozadu Bocage 1889, Paracontias, Mocquard 1894, Pseudacontias, Hewitt 1929, et Malacontias, Greer 1970; IV. Amphiglossus reticulatus (Kaudern, 1922) nov. comb., troisième espèce du genre; ses rapportsavec Amphiglossus waterloti (Angel 1920). Bull. Mus. natn. Hist.nat., Paris, 4th ser., sect. A., 2(3), 905-18.

Brygoo, E.R. (1981). Systématique des lézards scincidés de la région malgache, VI. Deux scincidés nouveaux. Bull. Mus. natn. Hist. nat., Paris, 4th ser., sect. A., 3(1), 261-8.

Brygoo, E.R. (1984). Systématique des lézards scincidés de la région malgache, XIII. Les Amphiglossus du sous-genre Madascincus. Bull. Mus. natn. Hist. nat., Paris, 4th ser., sect. A., 6(2), 527-36.

Brygoo, E.R. \& Böhme, W. (1985). Un Zonosaurus nouveau de la région d'Antseranana (= Diégo-Suarez, Madagascar) (Reptilia: Cordylidae). Rev. fr. Aquariol, 12(1), 31-2.

Carlton, M.D. \& Schmidt, D.F. (1990). Systematic studies of Madagascar's endemic rodent (Muroidea; Nesomyinae): an annotated gazetteer of collecting localities of known forms. Novitates, 2987, 1-36.

Domergue, C.A. (1984). Notes sur les serpents de la région malgache, IV. Le genre Pararhadinaea Boettger, 1898. Descriptions d'une espèceet d'une sous-espèce nouvelles. Bull. Mus. natn. Hist. nat., Paris, 4th ser., sect. A., 6(1), 149-57.

Green, G.M. \& Sussman, R.W. (1990). Deforestation history of the eastern forests of Madagascar from satellite images. Science, $N Y, 248,212-15$.

Guibé, J. (1958). Les serpentes de Madagascar. Mém. Inst. scient. Madagascar. Ser. A, 12, 189-260.

Guibé, J. (1978). Les batraciens de Madagascar. Bonn. Zool. Monogr., 11, 1-140.

Humbert, H. (1955). Les térritoires phytogeograpiques de Madagascar, leurcartographie. Ann. Biol. (3 ser.), 31, 195-204.

IUCN/UNEP/WWF (1987). Madagascar, an environmental profile, ed. M.D. Jenkins. IUCN, Cambridge.

Kluge, A.G. (1991). Boine snake phylogeny and research cycles. Misc. Publs Mus. Zool. Univ. Mich., 178, 1-58.

Loveridge, A. (1942). Revision of the Afro-oriental geckos of the genus Phelsuma. Bull. Mus. comp. Zool. Harv., 89(10), 439-82.

MacPhee, R.D.E. (1987). The shrew tenrecs of Madagascar: systematic revision and Holocene distribution of Microgale (Tenrecidae, Insectivora). Novitates, $2889,1-45$.

Mertens, R. (1964). Studien über die Reptilienfauna Madagaskars, V. Fünf neue Rassen der Geckonengattung Phelsuma. Senck. biol., 45(2), 99-112.

Nicoll, M.E. \& Langrand, O. (1989). Madagascar: Revue de la conservation et des aires protégées. WWF, Gland.

Pasteur, G. \& Blanc, C.P. (1967). Les lézards du sous-genre Malgache deLygodactyles Domerguella (Gekkonidés). Bull. Soc. Zool. France, 92(3), 583-97.

White, F. (1983). The vegetation of Africa. A descriptive memoire to accompany the UNESCO/AETFAT/UNSO vegetation map of Africa. Natural Resources Research, 20. UNESCO, Paris. 